Vol. 7, No. 1, 2021

UDC 72.03+725.7

Adriana Hromnyuk

\title{
CONCEPTUAL ANALYSIS OF THE ARCHITECTURE OF MODERN INTERIORS OF FOOD FACILITIES IN LVIV, KYIV AND ODESA
}

\author{
Assistant of the Department of Design and Architecture Fundamentals \\ Lviv Polytechnic National University, Lviv \\ e-mail: adja304@gmail.com \\ orcid: 0000-0003-0248-1218
}

Received: 04.03.2021 / Revised: 21.03.2021 / Accepted: 20.04.2021

(C) Hromnyuk A.. 2021

https://doi.org/10.23939/as2021.01.032

Astract. Based on the conceptual analysis of the subject-spatial environment of modern food enterprises in the cities of Lviv, Kyiv and Odesa, the features of their thematic and functional directions are highlighted, and a classification of semantic and artistic-figurative solutions for interiors of premises for visitors to these institutions is developed. Their varieties are defined according to the following characteristics: style direction, plot-thematic direction, genre-content and subject-sensory content, gastronomic specialization, imitation or reproduction of a certain historical type of food establishments. The main approaches to designing the architecture of modern interiors of food enterprises in the context of their artistic and figurative solution are formulated. An additional range of services and special functions that complement the conceptual design of thematic institutions are identified. The main trends in increasing the relevance and identification of food enterprises are identified.

Key words: conceptual analysis, interior architecture, artistic and figurative solution, varieties, food facilities.

\section{Problem statement}

Nowadays food facilities are an important component of the thematic and image structure of large cities in Ukraine. Their main task, in addition to the gastronomic one, is to surprise and catch visitors, impress and make them desire to return. That is why we observe a growing number of non-standard original food establishments of various types, distinguished by innovative solutions and a rich range of services. Their concept, thematic direction, artistic and figurative solution are key concepts.

For several years in a row, experts and restaurateurs have been choosing the top 100 Best Restaurants in Ukraine. Among the cities, the largest number of restaurants included in this list is represented by Kyiv, Odesa and Lviv (LLC "Publishing House "Media-DK", 2014-2021). Kyiv, as the capital of Ukraine, impresses with the variety and number of modern food establishments, characterized by innovative approaches to their design, the versatility of gastronomic and thematic directions. Lviv is a European city with a long history, formed at the intersection of different cultures, nationalities. It is a centre of intellectual property and rich traditions. Today Lviv is one of the most attractive cities for tourists thanks to thematic and interactive food establishments, museums etc. Odessa has long been famous for its 
local flavour, exceptional humour and a kind of multinational culture, which is fully reflected in the interiors of local food establishments. They convey both the peculiar mentality, hospitality, values and traditions of the inhabitants of this bright city. We should analyze the artistic and figurative solution to the interior architecture of modern food enterprises in these cities and identify their conceptual and functional features.

\section{Analysis of recent research and publications}

Certain aspects of the problem of conceptual and thematic solution of interiors in modern spaces, in particular public structures, are reflected in scientific periodicals of V. Andriyashko, D. Haraida (Harayda, D., 2017, p. 315-321), A. Hromnyuk, Yu. Dranytskyi (Dranyts'kyy, Yu., 2015, p. 180-187), V. Melnyk (Mel'nyk V., O. I. Morklyanyk, 2019), N. Novoselchuk (Novosel'chuk N. Ye., 2017), O. Smolyar (Smolyar, O., 2017, p. 977-982), Chernyavskyi K.

Theoretical issues of designing the interior architecture of food enterprises are revealed in the works of E. Ahranovskyi, V. Aladov, S. Bahmut, V. Batrymenko, V. Berdychevskyi, I. Hililov, L. Hritsyuk, L. Huseva, N. Denysova, B. Dmytriev, V. Yezhov, D. Yezhov, S. Yezhov, N. Ivanova, V. Karsekin, T. Kilpe, M. Klikich, V. Kokurin, B. Kurlishchuk, L. Lebedeva, S. Linda, F. Lawsan, V. Marhelov, T. Nikulenkova, Ye. Novikova, V. Ponomarenko, V. Chykolodkova, F. Chubarov, V. Yakubovskyi, H. Yastina. Fundamental works on the organization of interior architecture of food facilities are the works of V. Urenev (Urenev, V. P., 1988).

Modern catering enterprises of Kyiv, Lviv and Odesa (restaurants, bars and cafes), their conceptual and artistic solutions were the main source base for this study.

Despite the relevance of the approach of the conceptual design of the interior architecture of food facilities, it remains insufficiently explored in the modern theory of architecture, there are no comprehensive studies on this issue.

\section{Pu rpose of the article}

The article aims to carry out a conceptual analysis of the subject-spatial environment of modern food facilities in Lviv, Kyiv and Odesa, taking into account their thematic diversity and versatility; to develop scientific foundations and modern approaches to their design in the context of artistic, figurative and thematic solutions of interiors for visitors to these facilities.

\section{Results and discussion}

Nowadays in architectural practice, we are discovering new approaches to organizing the interiors of food facilities. The conceptual solution occupies a leading place in the design of modern spaces. This allows the development of innovation, individual search and non-standard solutions, as well as the integration of modern technologies and materials into the project process.

The "concept" means an idea, the meaning of the work (Bilodid, I. K., Buryachok, A. A., Dotsenko, P. P. red., 1973. p. 275). The conceptual idea/concept is reflected in the artistic image (Shevnyuk, O. L., 2015, p. 10). The author shows his interpretation of reality through the prism of an emotional worldview. The thematic direction (in our case, interior architecture) is manifested in the ideological content: any topic can be interpreted and expressed with the help of various ideas (Shevnyuk, O. L., 2015, p. 11). Thus, the creative process of a designer/architect involves finding a concept/idea that appeals to a particular theme, plot, motif or genre and is embodied in an artistic image.

The artistic and figurative solution of the interior architecture of food enterprises plays a key role in shaping the overall atmosphere of the institution, provides for the creation of an appropriate mood for visitors. It directly affects the choice of functional and especially artistic and decorative means. It is 
established that it concerns the design of interiors for visitors mainly of such food enterprises: restaurants, cafes, bars and eateries. It is these establishments that can specialize in the production of dishes and drinks of a certain direction (for example, national/regional cuisine), depending on the range of products sold (Hromnyuk, A. I., 2016, p. 107).

Based on the conceptual analysis of the interior architecture of modern food facilities (restaurants, bars, cafes and eateries) in Lviv, Kyiv and Odesa, the themes, plots, and motifs revealed in the artistic and figurative solution are determined. Ethnic motifs are extremely popular. You can also find themes of nationalities and countries - in such establishments, the national symbols of a certain state are used, for example, in the restaurant "The Mexican" (Lviv).

Motifs of films, TV shows, legends, fairy tales, and comics are widely used in the interiors of modern food establishments. The gastro cafe "Vivsianka, sir" (eng. "Oatmeal, sir") (Lviv) recreates the atmosphere of Sherlock Holmes' apartment, here you can also see portraits of actors who played his role. Cafe "Friends" (Kyiv) conveys the mood of the TV series of the same name, which visitors can watch there. You can see the interior, reminiscent of the fairy tales of 1001 Nights, by visiting the restaurant "Tubyteika" (Kyiv). In the "Comics cafe" (Kyiv), there is a theme of comics, which can be purchased here. In the artistic image of the interiors of modern food establishments, you can find the themes of music, theatre, circus: the restaurant "Deja Vu" (Kyiv) conveyed the spirit of rock-n-roll; the interior of the restaurant "Café Theater" (Kyiv) resembles a real theatre hall with curtains and balconies.

Especially popular are the themes of epochs or historical periods of different countries and peoples, in which the atmosphere of a certain time and place is recreated. This is, in particular, the restaurant "Knyazhy Hrad", which has the theme of the times of Kievan Rus; the restaurant "LOU LOU" (Odessa), which resembles the establishments of Paris (Montmartre St.) at the beginning of XX century. The interior of the cafe-bakery "Breadway" recreates the style and mood of American cafes of the 50s and 60s. of XX century; the subject-spatial environment of the cafe "Sanatorium "Lastivka" (Lviv) and the restaurant "Molodist" (Kyiv) conveyed the atmosphere of everyday life of Ukrainians in the period of the 90s. You can take a dip into the Middle Ages by visiting the restaurants "Pyate pidzemelia" (eng. Fifth dungeon) Lviv) and "Legend" (Odessa). The theme of inventions is also now reflected in the interiors of food establishments, where visitors can get acquainted with artefacts and interesting historical exhibits. Often such establishments include museums, such as the restaurant-museum "Hasova Liampa" (eng. "Kerosene lamp").

Common topics are those dedicated to a particular person and their life path. For example, the restaurant "Frankova kuznya" (Lviv) is dedicated to an outstanding Ukrainian writer, poet, public figure I. Franco; restaurant "Bartholomew" (Lviv) tells about the personality of the Lviv Mayor of the XVII century Bartholomew Zimorovich. In the interiors of food establishments, there is also a theme of childhood, for example, in the restaurant "Mamatsiluvala" (Kyiv).

An interesting artistic and figurative solution is characterized by establishments that reflect the themes of the city, village, such as the restaurant "Adele" (Kyiv), which conveys the atmosphere of the streets of Tel Aviv. The restaurant "Odesa-Mama" (Kyiv) recreates the Southern flavor and sea mood of the Odesa port city. In our opinion, the theme of nature (Sea, Forest, etc.) is relevant in food establishments, which help visitors to relax as much as possible and set them up for harmony. These are, for example, the restaurants "Rabbit Habit" (Kyiv), "Kobe" (Odesa), "36 Po" (Lviv). The theme of fish and animals can also be seen today in the interiors of such food facilities as fish restaurants "Flagman", "Marlin" (Kyiv), etc.

In the artistic and imaginative solution of food enterprises, the theme of sports and hobbies is relevant as well. For example, in sports bars "Arena Sport Bar" and "Frankie Sport Bar \& Bazabet" (Kyiv). The theme of the revolution and the rebels is reflected in such institutions as "Ostannia barykada" (eng. "The Last Barricade") (Kyiv) and "Kryivka" (Lviv); the military theme is found in the veteran restaurant "Patriot" (Lviv), which was opened by former ATO servicemen; in the cafe "Unit military" (Odesa). 
The themes of the house, castle and cottage are common today. Thus the restaurant "DOM No. 10" recreated the atmosphere of a private house of the twentieth century; the restaurant "Finvarra pub" (Kyiv) is like a medieval castle-fortress; in the restaurant "Dacha" (Odesa) is the atmosphere of dachas of the 30s of XX century. An unusual artistic and figurative environment is represented by food enterprises that imitate the interiors of specialized institutions: hospitals (cafe-bar "Palata № 6" (eng "Room №. 6") in Kyiv), meat shop ("Steakhouse" restaurant in Kyiv), sewing studio (cafe-coffee shop "Atelier. Coffee \& Crafts" in Odesa).

Often, the historical past of a building - the type of institution, its primary functions and stylistic solution - dictates the concept of the institution and its thematic direction. For example, the confectionerypharmacy "Pid Zolotoyu Zirkoyu" ("Under the Golden Star") in Lviv is an interactive museum where you can see authentic kerosene lamps, restored interior items and posters of the XIX century.

In recent decades, food establishments specializing in the production of dishes of national cuisines and in the interiors of which ethnic motifs are used have gained considerable popularity. These are in particular East Asian cuisines: Japanese, Chinese and Korean; Caucasian cuisine: Georgian, Armenian, Azerbaijani, Uzbek, Arabic: Moroccan, Lebanese, Persian cuisine, Mexican, Indian, Turkish and Brazilian, African, Vietnamese, Polynesian, Indonesian and Thai cuisines, Greek and other Balkan cuisines, Italian, Israeli, Hungarian, Czech, Spanish, etc.

Of course, the most common establishments in our country are the facilities with Ukrainian folk cuisine. Designing the architecture of their interiors takes into account the cultural traditions, folk architectural and artistic heritage of a particular ethnographic region. It is determined that the use of ethnic motifs in the spatial environment of food enterprises is carried out using the following methods: stylization of architectural and structural elements, furniture and equipment, decor; direct reproduction of samples of the folk architectural and artistic heritage of a particular people/ethnographic region; the use of authentic elements and objects of decorative and applied art (furniture, carpets, towels, embroidery, tablecloths, vases, decorative dishes, tools etc.); synthesis of stylization using modern interior items and authentic or recreated elements of ethnic culture (Hromnyuk, A. I., 2016, p. 129).

Sometimes modern food enterprises are an imitation or reproduction of a certain type of food enterprises of a particular country or historical period. For example, in 2002 in Lviv, the kneipp "Atlas" was restored, which operated in the early twentieth century and the 1920s and 1930s the facility was very popular among the residents of the city. The restaurant operates in the same building.

Interior of the cocktail bar "Parovoz Speak Easy" (Kyiv) is an imitation of the classic New York "speakeasy" bar - an illegal institution that sold alcoholic beverages during Prohibition in the United States. Varenichna "Pobeda" ("Victory") (Kyiv) is the epitome of a Soviet-era diner with national dish varenyky.

The Interior of the restaurant "Liberty Diner" (Kyiv) resembles American diners. The diner is a type of fast-food restaurant found in the northeast, southeast, and midwest of the United States, and is also common in other parts of the United States, Canada, Serbia, and Western Europe.

Modern analysis of the spatial environment of modern food enterprises allowed the author to significantly expand and refine his classification of semantic and artistic-figurative solutions of interiors of premises for visitors to these institutions (Table 1).

Classification is based on the following criteria:

- by style direction (most interior elements are subordinated to a relevant recognizable style or style direction): art deco, high-tech, minimalism, eclecticism, loft, modern classics, steampunk, provance etc.;

- by the plot-thematic direction (in the artistic and figurative solution of the interior can be traced plot, recognizable motif/theme): ethnic motifs; themes of nationalities, countries; motifs of fairy tales, legends; films, TV shows; comics; themes of music; theatre, circus; epochs or historical periods; themes dedicated to a certain person and his life path; themes of childhood; themes of cities, villages; nature (sea, forest etc.); themes of fish, animals; themes of sports and hobbies; inventions; themes of revolution, rebels; military theme; home, castle, dacha; specialized institutions, facilities: hospital, workshop, sewing studio; 
- by genre-content and subject-sensory content (the interior uses signs that associatively appeal to a certain genre, a way of a worldview that is built on emotional-sensory categories, artistic and aesthetic ideals): mysticism, romance, science fiction, theatricalization, decorativeness, absurdity, provocation, grotesque.

- by gastronomic specialization (in the artistic solution of the interior, the dominant is figurative reinterpretation, stylization of the main dish/drink, which is "branded" in the institution (often has a humorous character)): meat dishes; fish dishes; drinks (coffee); alcoholic beverages; desserts; pizza.

- by imitation or reproduction of a certain historical type of food establishments (the interior is built based on the imitation of the subject-spatial environment of historically formed types of food establishments of different countries and cultures, periods): kneipp, "speakeasy" bar, diner, varenychna, etc. (Hromnyuk, A. I., 2016, p. 95).

Separately, we can distinguish the feature of artistic and figurative solutions for placing food establishments in atypical premises, in particular, vehicles, for example, in a former tram: restaurant "Tram No. 16" (Odesa).

Some food establishments strive to stand out not only with the help of interesting topics, which is manifested in the figurative solution of their interior architecture but also offering visitors additional functions and services that often complement the conceptual idea and allow them to spend a diverse and informative time, bringing people together according to common interests. Among them is the "Knyharniakaviarnia Staroho Leva" (a book and coffee shop in Lviv), where visitors can read books, meet with Ukrainian and foreign writers, or listen to lectures by cultural figures. A similar function has the cafe "One LOVE coffee" (Kyiv), where there is an art library of the publishing house "Taschen".

Table 1

\section{Classification of semantic and artistic solutions of interiors of premises for visitors of food facilities}

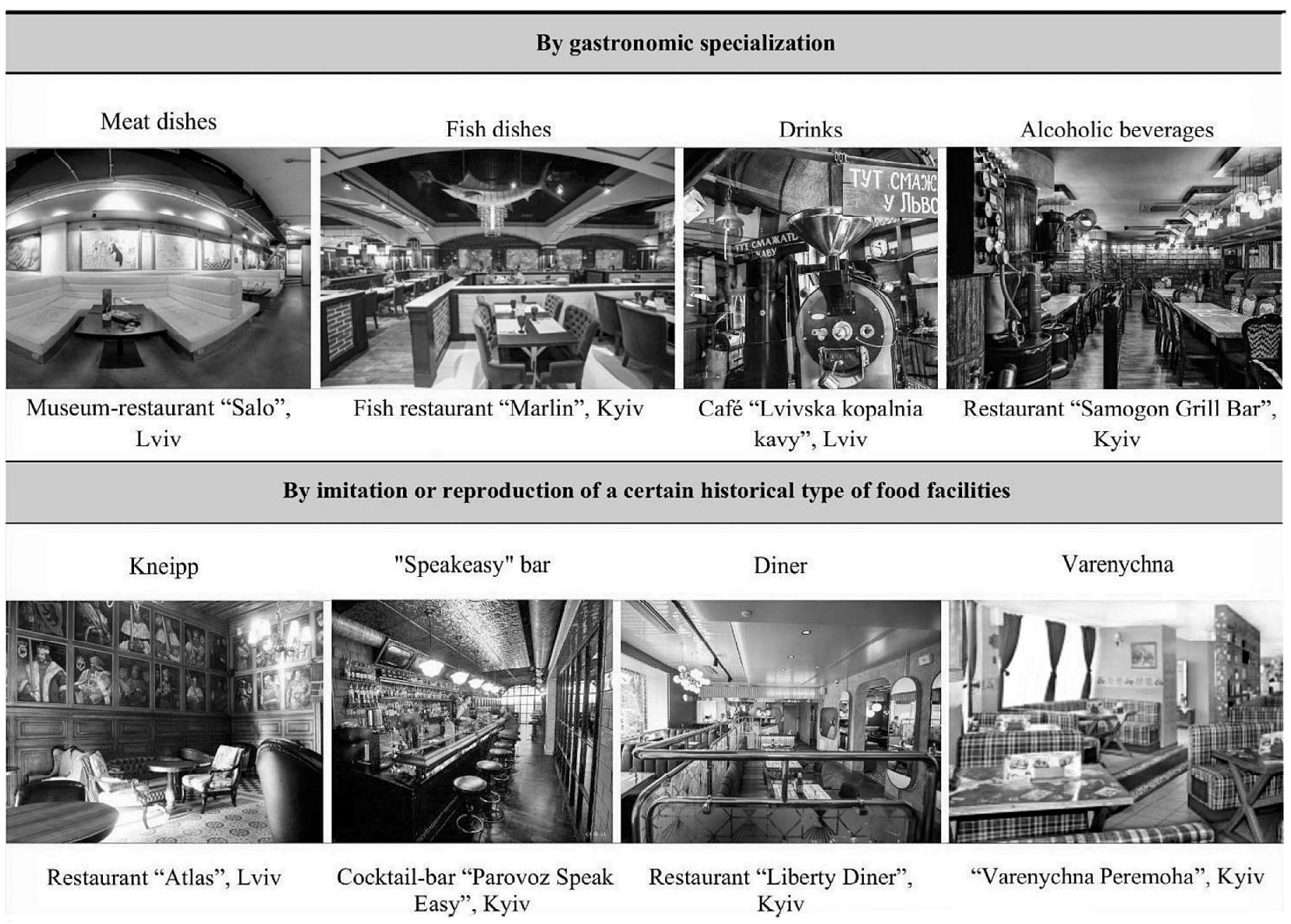


Continuing table 1

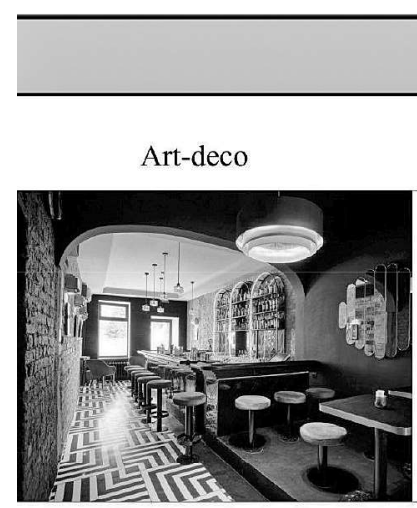

Bar «Talkies», Kyiv

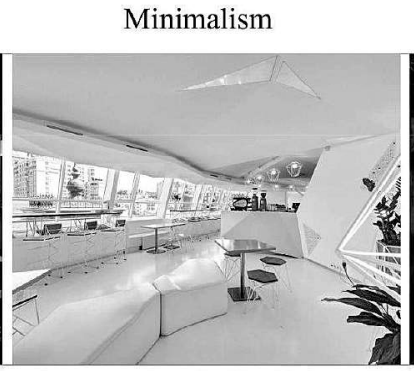

Café "ONE LOVE", Kyiv
By style

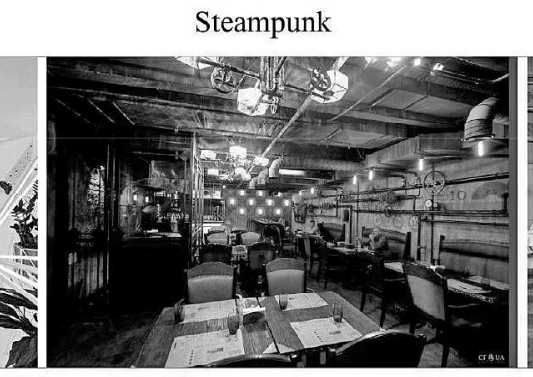

Restaurant "ONE LOVE", Kyiv
Eclecticism

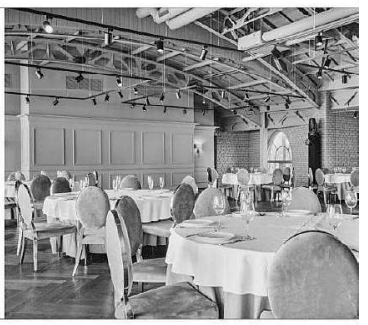

Restaurant "YUG", Odesa

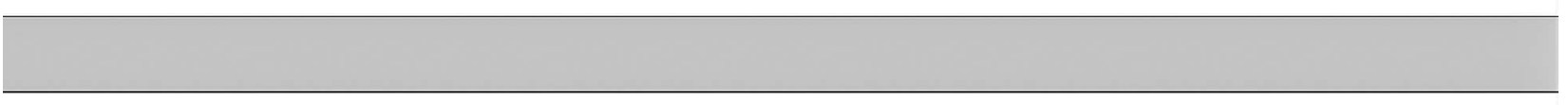

Loft

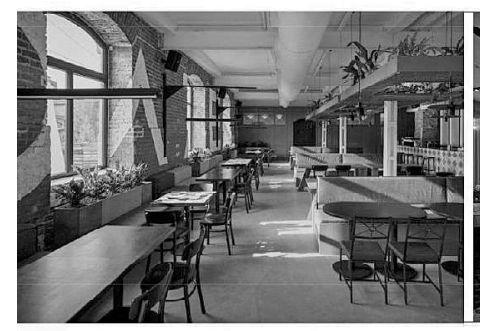

Gastropub "MolodoZeleno", Lviv
Modern classics

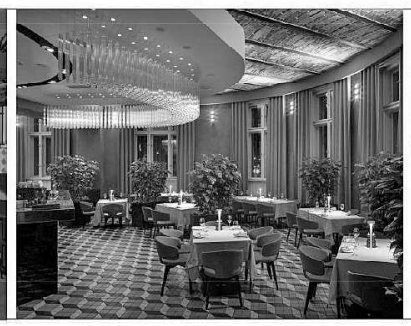

Restaurant "Safe", Lviv
High-tech

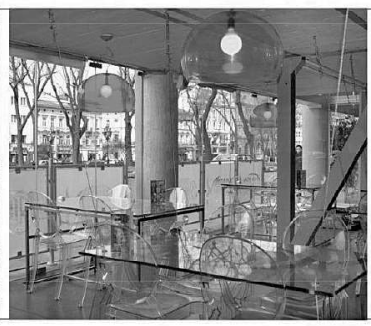

Restaurant "Yapi", Lviv
Provance

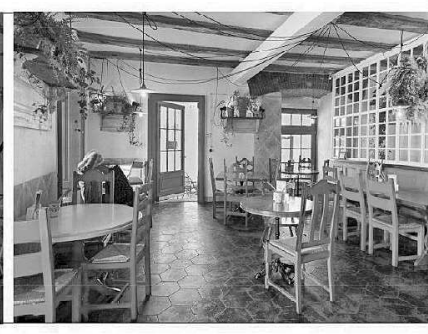

Restaurant "Tante Sophie", Lviv

By genre-content and subject-sensory content

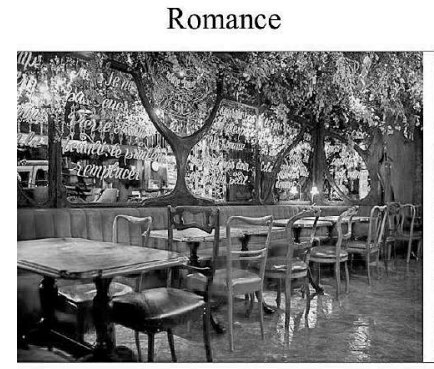

Wine restaurant "Wine love", Kyiv

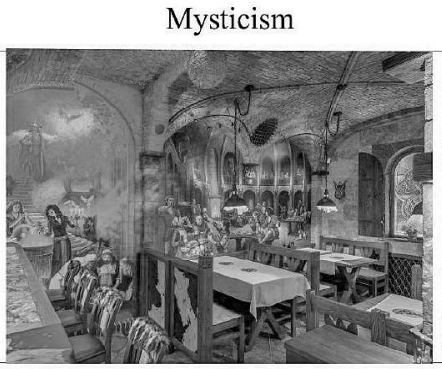

Reslaurant "Mediaval Finvara Pub", Kyiv

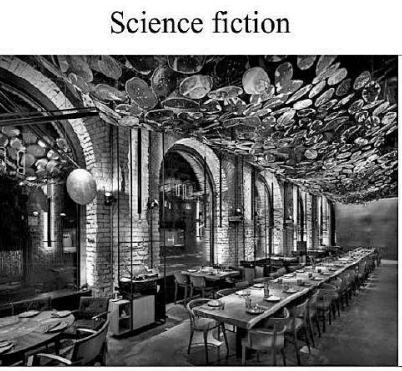

Reslaurant "BAO”, Kyiv

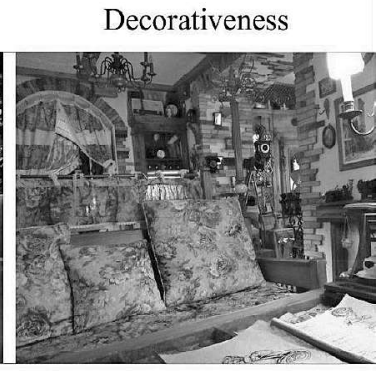

Café "Zhelo", Odesa

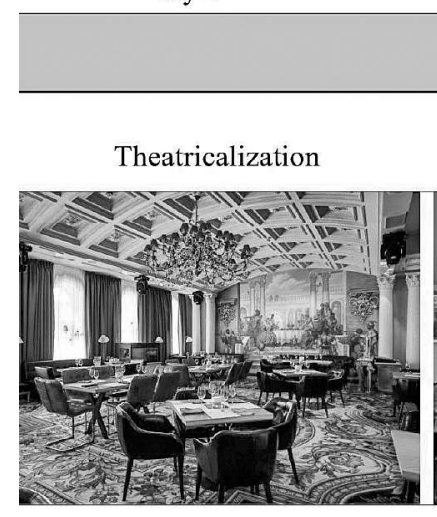

Restaurant "Mario", Kyiv
Absurdity

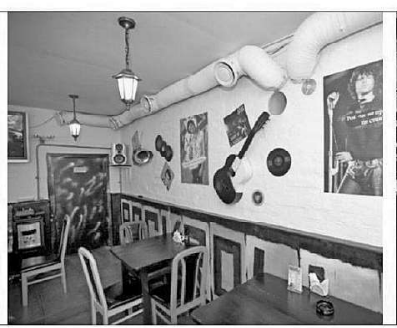

Absurd-pub "BarDuck", Kyiv
Provocation

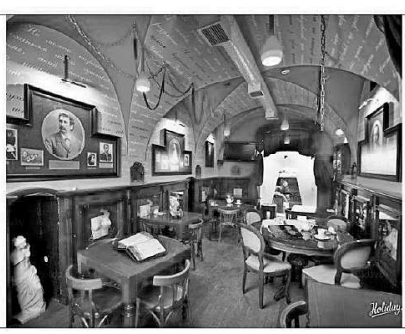

Café "Mazoh", Lviv
Grotesque

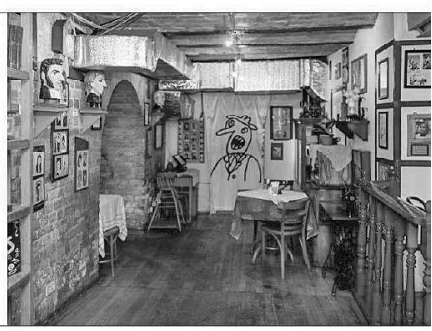

Club-restaurant "Petrovych", Kyiv 
By the plot-thematic direction

Ethnic motifs

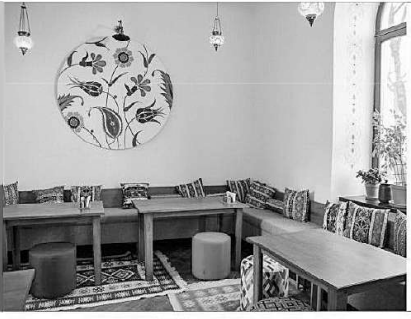

Restaurant "Plove House", Lviv
Themes of nationalities, countries

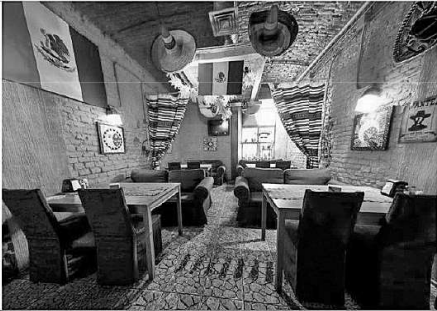

Restaurant "The Maxican", Lviv

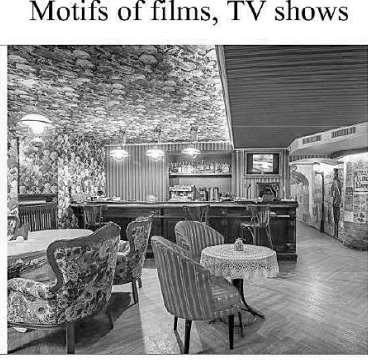

Restaurant "Za dvoma zaichiamy", Kyiv
Motifs of fairy tales, legends

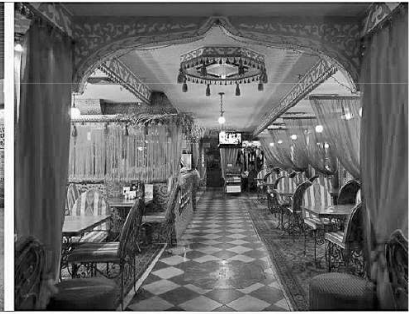

Restaurant "Tubyteika", Kyiv

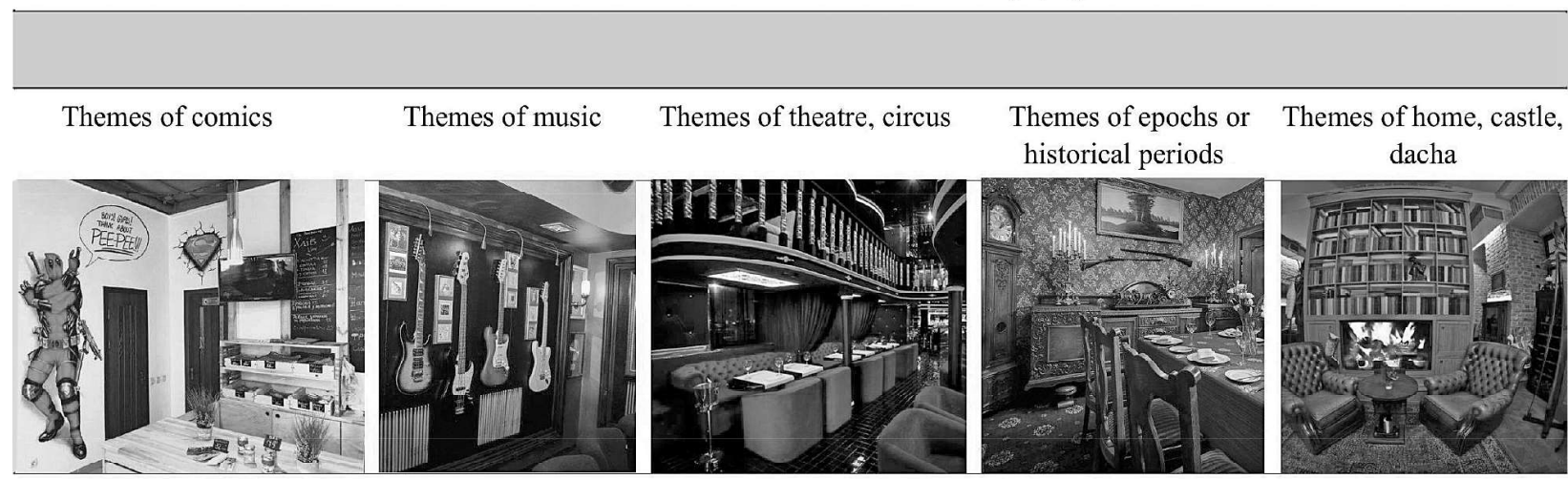

Café "Comics Café", Kyiv Restaurant "Dejavu", Restaurant "Café theatre", Restaurant "Antwerpen", Restaurant "Uliublenyi Kyiv Kyiv Kyiv diadko", Kyiv

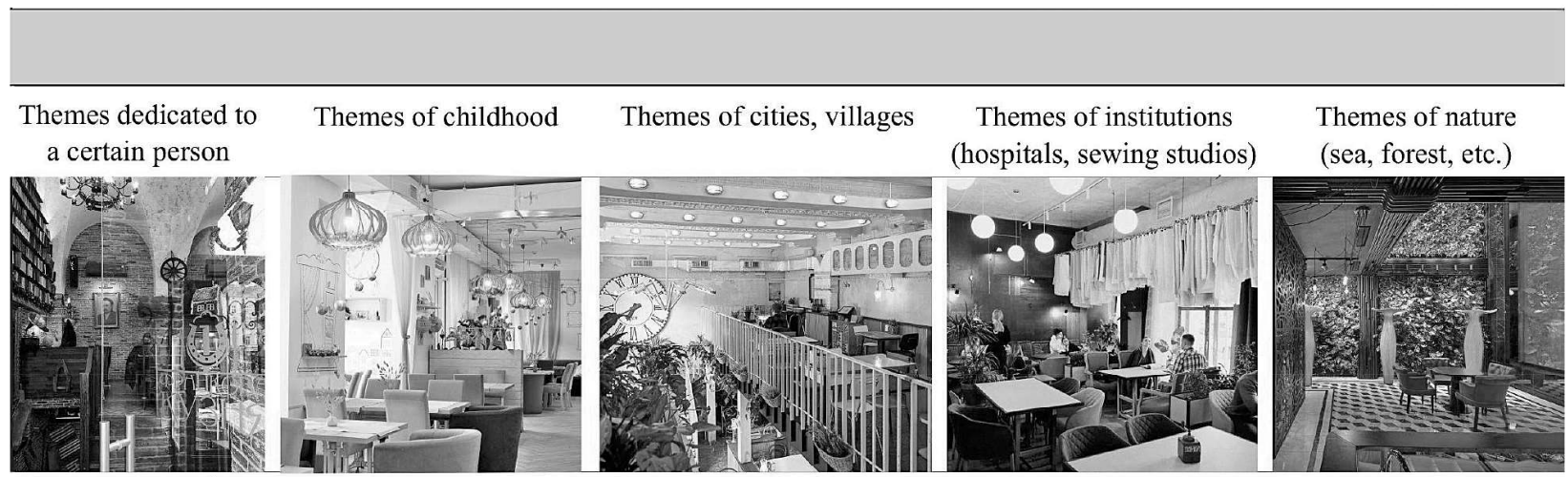

Restaurant "Frankova Restaurant

kuznia", Lviv

"MamaTsiluvala", Kyiv

Restaurant "Adel", Kyiv

Cafe "Atelier. Coffe \& Crafts", Odessa

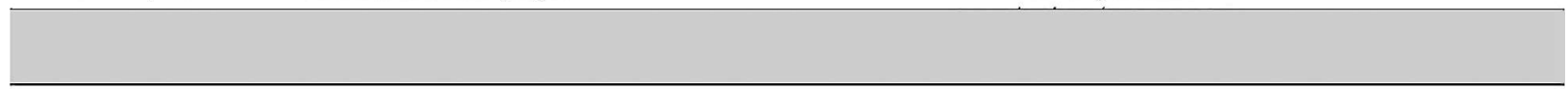

Themes of fish, animals Themes of sports and hobbies Themes of inventions

Military theme

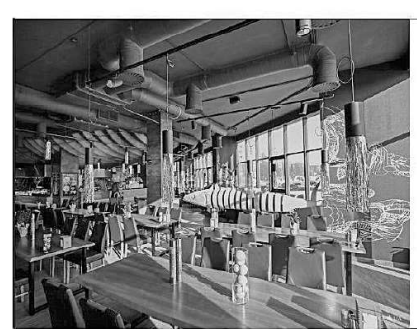

Fish shop-restaurant

"Flagman", Kyiv

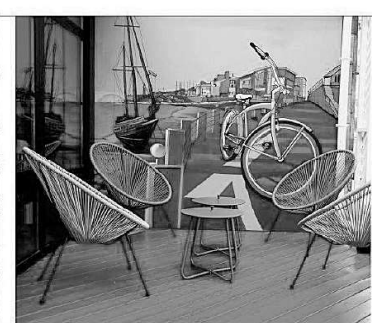

Café-bar "Velocity", Kyiv

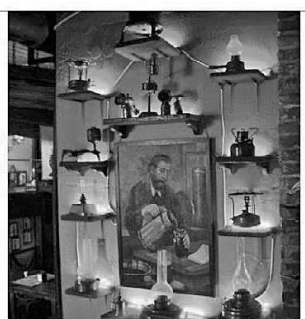

Restaurant-1museum "Hasova liampa", Lviv

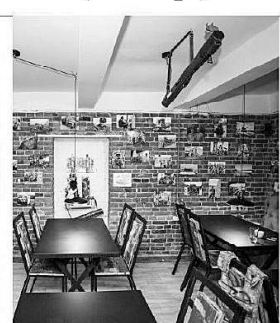

Restaurant "Patriot", Lviv
Themes of revolution, rebels

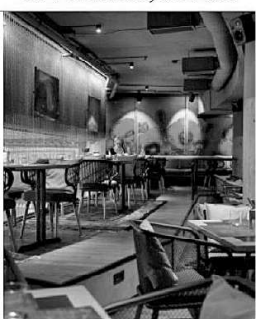

"Ostannia barykada", Kyiv 
An interesting concept has the restaurant "Razzle Dazzle" (Kyiv), a special feature of which is the theatre: on weekends, theatrical performances take place here. In the restaurant "Yablochko" (Kyiv) guests can lose in the game of darts; and the cafe-bar "Velocity" (Kyiv) offers bike repair services, there is a bicycle parking lot on the territory; the staff is ready to help bike enthusiasts with tools and spare parts. In the restaurant "Kanapa" (Kyiv) there are chamber music concerts, and in the facility "Duzhe Vysoka Kuhnia" visitors can listen to music from vinyl records through horn speakers. Kinorestoran "RE'LUX" (Kyiv) offers a combined cinema hall with a dining hall.

Popular establishments for children are specialized cafes or family restaurants that have a separate children's playroom, a children's menu, such as the children's cafe "Baby-Rock" (Kyiv), restaurant "Mamatsiluvala" in Kyiv, cafe "Bilka" (Lviv) and others.

An innovative health cafe operates in Kyiv - "Soliana Pechera" ("Salt Cave"), staying in which has a positive effect on the respiratory tract and contributes to recovery. Another place with extraordinary offers is "Cat Cafe" (Lviv), which is created for cat lovers. Here visitors can enjoy the company of these animals, as well as pet and feed them.

A special feature of the restaurant "Holodnyi Mykola" ("Hungry Mykola") (Lviv) is the presence of a double Lake, one part of which is located in the restaurant, the other on the street. Visitors have the opportunity to catch trout on their own, and the chefs will prepare it. In the bar "BarDuck" (Kyiv) guests are invited to play board games: chess, poker, yo-yo, perform "stand-up" or sing karaoke.

Sometimes in the interiors of food facilities, there are exhibitions of artists ("Svit kavy", Lviv; "Kanapa" (Kyiv); "Barvy", (Kyiv). Some restaurants provide for dancing and parties: they play the role of night clubs, like the restaurant-club "Faces" (Lviv). In Kyiv "Comics Café", in addition to a pastry shop and cafe, there is a comics book store.

Nowadays we often see the museums operating at food establishments, mostly they are related to the history of the institution or its thematic focus. Thus, the restaurant "Ostannia barykada" (Kyiv) has the museum of three Ukrainian modern revolutions; restaurant - Museum "Hasova Liampa" (Lviv) is famous for the exhibition of 528 kerosene lamps; in the photo cafe "Fixage" (Lviv) there is a museum of ancient photographic equipment and a film club. Coffee shop "Poshta na Drukarskiy" is the last analog post office in Lviv. Here is the largest collection of Lviv postal artefacts: old postcards and stamps, telephone sets; you can also create your postcard and send it to the addressee.

In some establishments, there is a shop where you can buy branded products or souvenirs ("Maisternia Shokoladu", "Kopalnia Kavy", Lviv).

Thematic interactive establishments invite visitors to become part of the demonstration event for entertainment purposes. This attraction is especially attractive for tourists, as well as for residents. Often non-standard offers and services are spelt out in the menu and complement the conceptual idea of the institution.

Based on the conceptual analysis of the architecture of modern interiors of food facilities, the following approaches to their design are identified in the context of artistic and figurative solutions of interiors of premises for visitors to these institutions:

- conceptualism (provides for the existence of a concept as a single leading idea, provides a creative author's approach to design and the development of uniqueness);

- eclecticism (manifested in the tendency to combine elements of several different styles, adapt historical styles to a modern manner);

- environmental friendliness (provides for the use of environmental design principles, energy-saving means and systems, natural materials, development of photo design, landscaping of modern spaces, etc.);

- traditionalism (preserving and reproducing cultural and historical traditions, using the architectural and artistic heritage of the past; provides for the restoration of authentic architectural and artistic elements, their citation or stylization);

- functionalism (manifested in the superiority of the functional component over the aesthetic one, consists in creating practical ergonomic spaces, the basis of which is a comfortable stay of visitors, the functionality of their elements and the limited artistic means); 
- symbolism (provides for figurative and symbolic reproduction of reality, individual interpretation of certain symbols hidden in certain images; helps to strengthen the artistic expressiveness of interiors, appeal to the emotional and sensory perception of visitors);

- innovation and experimentalism (focused on discoveries and innovative solutions in design, the use of the latest technologies and developments; direction - to surprise, amaze).

The analysis of the conceptual solution of the interior architecture of catering enterprises allowed us to identify the main current trends in increasing the relevance, attractiveness and identification of food establishments that contribute to increasing their popularity, attendance and attractiveness. This is a gastronomic specialization; an emphasis on artistic and figurative solutions; versatility and availability of additional services; interactivity.

\section{Conclusions}

The article provides a conceptual analysis of the subject-spatial environment of modern food enterprises in Lviv, Kyiv and Odesa, which are famous for the greatest variety of extraordinary thematic and multifunctional institutions.

Classification of semantic and artistic-figurative solutions of interiors of premises for visitors of these institutions has been developed. Their varieties are defined according to the following characteristics: style direction, plot-thematic direction, genre-content and subject-sensory content, gastronomic specialization, imitation or reproduction of a certain historical type of food establishments. It is established that the concept of an institution and its thematic direction are also often influenced by the historical past of the building: the type of institution, facility, its primary functions and stylistic solution.

The main approaches to designing the architecture of modern interiors of food enterprises in the context of their artistic and figurative solutions are formed: conceptualism, eclecticism, environmental friendliness, traditionalism, functionalism, symbolism, innovation and experimentalism.

It is revealed that the general concept of food enterprises often goes beyond the artistic and figurative solution of the interior architecture of their premises for visitors and is reflected in the additional specific services of these institutions. Nowadays, there are different functions of restaurants and cafes except the function of food. These are, in particular, the functions of health improvement, cultural and educational (the presence in institutions of museums, bookstores, libraries, lectures and thematic meetings, master classes, music concerts, exhibitions), entertainment (fishing, cinema hall, disco club, karaoke, stand-up performances, theatrical interactive actions, providing a variety of games), the presence of a bicycle workshop, a children's room, a themed shop, the possibility of spending time with animals.

The main trends in increasing the attractiveness and identification of food establishments that contribute to increasing their popularity, attractiveness and attendance are identified: gastronomic specialization; emphasis on artistic and figurative solutions; versatility and availability of additional services; interactivity.

\section{References}

Hromnyuk, A. I., 2016. Ethnic motives in the architecture of modern interiors of catering industry. Candidate's thesis. Lviv Polytechnic National University.

Urenev, V. P., 1988. Inter'yer ta obladnannya pidpryyemstva hromads'koho kharchuvannya [Interior and equipment of catering establishments]. Kyyiv : Budivel'nyk.

Bilodid, I. K., Buryachok, A. A., Dotsenko, P. P. red., 1973. Slovnyk ukrayins'koyi movy: v 11 tomakh [Dictionary of the Ukrainian language: in 11 volumes]. [online] Vol. 4. Kyiv : Naukova dumka. Available at: <http://sum.in.ua/s/koncepcija $>$ [Accessed date: 23 March 2021].

Harayda, D., 2017. Stylistics as one of the methods of interior design of catering establishments in Western Ukraine. Visnyk L'vivs'koyi natsional'noyi akademiyi mystetstv, [online] issue 31, p. 315-321. Available at: <http://nbuv.gov.ua/ UJRN/Vlnam_2017_31_31>[Accessed date: 23 March 2021]. 
Dranyts'kyy, YU., 2015. Interior design of modern hotel complexes in Ukraine: conceptual approaches to design. Visnyk L'vivs'koyi natsional'noyi akademikh mystetstv, [online] issue 26, p. 180-187. Available at: <http://nbuv.gov.ua/UJRN/Vlnam_ 2015_26_21> [Accessed date: 23 March 2021].

Mel'nyk V., O. I. Morklyanyk, 2019. Kontseptual'nyy pidkhid v arkhitekturnomu proektuvanni [Conceptual approach in architectural design]. 77th Student Scientific and Technical Conference, a collection of abstracts. [online] Lviv, Ukraine, October 2019. L'viv : Vydavnytstvo L'vivs'koyi politekhniky. Available at: $<$ http://ena.lp.edu.ua:8080/handle/ntb/53591> [Accessed date: 23 March 2021].

Novosel'chuk N. YE., 2017. Suchasni tendentsiyi obraznoho vyrishennya zakladiv hromads'koho kharchuvannya [Modern trends in the figurative solution of catering establishments]. Abstracts of the 69th scientific conference of professors, teachers, researchers, graduate students and university students. [online] Poltava, Ukraine, April 19 - May 19, 2017. Poltava : PoltNTU. Available at: $<$ http://reposit.nupp.edu.ua/handle/PoltNTU/3845> [Accessed date: 23 March 2021].

Smolyar, O., 2017. Conceptual analysis of works of monumental and decorative art in the interior design of hotels in Kiev 1950--1980's. Narodoznavchi zoshyty, [online] issue no. 4 (136), Instytut narodoznavstva NAN Ukrayiny, p. 977-982. Available at: <https://nz.lviv.ua/2017-4-28/> [Accessed date: 23 March 2021].

LLC "Publishing House "Media-DK", 2014-2021. HB website [online]. Available at: <https://life.nv.ua/ukr/fooddrink/top-100-luchshih-restoranov-ukrainy-2019-po-versii-nv-50018618.html> [Accessed date: 23 March 2021].

Shevnyuk, O. L., 2015. Slovnyk terminiv obrazotvorchoho mystetstva: Navchal'nyy posibnyk: [2-e vyd., vypravlene $i$ dopovnene] [Dictionary of terms of fine arts: Textbook: [2nd ed., Corrected and supplemented]. [online] Kyiv: Vyd-vo NPU im. M. P. Drahomanova. Available at: <http://enpuir.npu.edu.ua/handle/123456789/23107> [Accessed date: 23 March 2021].

Wikipedia, the free encyclopedia [online]. Available at: $<$ https://en.wikipedia.org/wiki/Diner> [Accessed date: 23 March 2021].

\title{
Адріана Громнюк
}

Канд. арх., асист. кафедри дизайну та основ архітектури Інституту архітектури та дизайну

Національний університет “Львівська політехніка", Львів e-mail: adja304@gmail.com orcid: 0000-0003-0248-1218

\section{КОНЦЕПТУАЛЬНИЙ АНАЛІЗ АРХІТЕКТУРИ СУЧАСНИХ ІНТЕР'ЄРІВ ПІДПРИЕМСТВ ХАРЧУВАННЯ МІСТ ЛЬВОВА, КИЄВА ТА ОДЕСИ}

\begin{abstract}
Анотація. У статті подано конщептуальний аналіз предметно-просторового середовища сучасних підприємств громадського харчування у Львові, Києві та Одесі. Вони славляться найбільшим розмаїттям надзвичайних тематичних та багатофункиіональних закладів. Розроблена класифікація смислових та художніх рішень інтер'єрів для відвідувачів uих закладів. Їх різновиди окреслені за такими ознаками: стилістичний напрямок, сюжетно-тематичний напрямок, жанровий зміст та предметно-чуттєвий зміст, гастрономічна спеціалізація, імітація чи відтворення певного історичного типу закладів харчування. Встановлено, що на кониепиію підприємства громадського харчування та його тематичну спрямованість також часто впливає історичне минуле будівлі: тип закладу, його основні функції та стилістичне рішення.

Сформульовано основні підходи до проектування архітектури сучасних інтер'єрів закладів харчування в контексті їх художньо-образного вирішення: концептуалізм, еклектика, екологічність, традиціоналізм, функиіоналізм, символізм, інноваиійність та експерименталізм. Визначено додатковий спектр послуг та спеціальних функиій, які доповнюють концептуальний дизайн тематичних установ. Це реабілітаційна, культурно-освітня функиія (наявність музеїв, книжкових магазинів, бібліотек, лекцій та тематичних зустрічей, майстер-класів, музичних концертів, художніх виставок), розваги (риболовля, кіно, дискотека, караоке, стендап-вистави, театральні вистави,, акиїі, що передбачають різноманітні ігри), наявність ремонту велосипедів, дитячої кімнати, тематичного магазину або можливість провести час із тваринами.

Визначено основні тенденції зростання актуальності та ідентифікачії закладів харчування, що сприяють зростанню їх популярності, привабливості та відвідуваності. Це: гастрономічна спеціалізація; акиент на художньообразне рішення; універсальність та доступність додаткових послуг; інтерактивність.
\end{abstract}

Ключові слова: концептуальний аналіз, архітектура інтер'єру, художньо-образне рішення, різновиди, заклади харчування. 